\title{
Energy Efficiency and Economical Benefits of Pigeonpea [Cajanus cajan (L.) Millsp.] - Neem (Azadirachta indica A. Juss.) Based agroforestry System under Rainfed Condition in North-Eastern Karnataka
}

\author{
M. G. Honnayya ${ }^{1} *$ Doddabasawa $^{2}$ and B. M. Chittapur ${ }^{3}$ \\ ${ }^{1}$ Department of Agronomy, University of Agricultural Sciences, Raichur, \\ Karnataka-584104, India \\ ${ }^{2}$ Department of Environmental Science and Agroforestry, Bheemarayanagudi, University of \\ Agricultural Sciences, Raichur, Karnataka-584104, India \\ ${ }^{3}$ Directorate of Extension, College of Agriculture, University of Agricultural Sciences, \\ Raichur, Karnataka-584104, India \\ *Corresponding author
}

A B S T R A C T

K e y w o r d s
pigeonpea [Cajanus
cajan (L.) Millsp.] -
neem (Azadirachta
indica A. Juss.)

\section{Keywords}

pigeonpea [Cajanus cajan (L.) Millsp.] neem (Azadirachta indica A. Juss.)

Accepted: Available Online:
The study was carried out during 2018-19 to evaluate energy efficiency and economical benefits of pigeonpea [Cajanus cajan (L.) Millsp.] - neem (Azadirachta indica A. Juss.) based agroforestry system in under rainfed condition North-eastern part of Karnataka, India. Among the directions, the energy use efficiency was non-significant. However, significantly lower EUE recorded with closer to tree line (2.20) and was increased as one moved away from the tree line and this was highest far away (3.31) from tree line. The gross returns were the maximum ( $₹ 55583 /-$ ha $^{-1}$ year $^{-1}$ ) with pigeonpea on southern side at a distance of 10.8 to $16.2 \mathrm{~m}$ other directions at similar distances were comparable, while those planted near the tree line at $<5.4 \mathrm{~m}$ on the western side recorded the lowest gross returns ( $₹$ 31029/- $\mathrm{ha}^{-1}$ ). Similar were the trends in net returns and B: C. The net returns and B: C were the maximum (₹ 40166/- $\mathrm{ha}^{-1}$ and 3.88, respectively) on southern side at 10.8 to $16.2 \mathrm{~m}$, while those planted near the tree line at $<5.4 \mathrm{~m}$ on the western side of the tree line recorded the lowest net returns and B: C (₹ 15612/- $\mathrm{ha}^{-1}$ and 2.33, respectively). Sole crop of pigeonpea had gross and net returns and B: C of ₹ 45259 and 29842/- ha $^{-1}$ and 2.97 respectively. Interestingly the agroforestry system of pigeonpea + neem with pigeonpea at $>10.8 \mathrm{~m}$ irrespective of direction of planting recorded higher returns and $\mathrm{B}$ : $\mathrm{C}$ than sole pigeonpea. In all, the economics followed crop yield and economic returns obtained from the tree component. Crop at $>10.8 \mathrm{~m}$ distance from neem have maximum EUE and economically profitable than sole crop.

\section{Introduction}

Trees are important components of nature and provide stability to biosphere. We cannot visualize life without trees and the history of trees/forests is linked with the progress of human evolution (Chittapur and Patil, 2017). However, with increasing population and corresponding rise in demands for food, forest products and land, pressure has increased on forests leading to destruction of forest area and quality of forests. Further, it is estimated 
that nearly, 27 per cent of India's population continues to depend on forests for their livelihood in some way or other and more than 50 per cent of the livestock population of the country depends on forest for grazing. Thus, the dependence of human population as well as livestock on forests all over the world to meet the requirements such as timber, fuel wood, fodder, food, medicines and other non timber forest products has led to degradation of forests, natural resources and depletion of floral/ faunal diversity. Hence, efforts to conserve and protect forest resources are urgently being intensified. Agroforestry systems (AS) are multifunctional land use systems where farmers deliberately retain woody perennials on the farm land with the primary objective to diversify the products (Chittapur et al., 2017) but AS also provides several ecosystem services which benefits the agriculture practices such as improvement in soil fertility, soil and water conservation, enhancement of water quality, carbon sequestration and biodiversity conservation (Jose, 2009, Chittapur and Patil 2017). Hence, in recent days agroforestry systems are considered to be best natural resource management strategy which will help to achieve the sustainability in agriculture.

Traditionally most preferred agroforestry system practiced by the farmers under rainfed ecosystem is scattered planting which is also called as parkland system. Farmers also prefer the trees on the bunds and farm boundaries with varying density of 15 to 40 trees per hectare in the study area (Doddabasawa et al., 2017). Among different species, neem (Azadirachta indica), a multipurpose tree species, prominently found in semi-arid regions, is deliberately retained by farmers on bunds and boundaries of farm land in order to get multiple benefits including indirect benefits like shade and stabilizing bunds.

Among the crops pigeonpea [Cajanus cajan (L) Millsp.], being leguminous plant with deep tap root system and drought tolerant characteristics, is a more successful crop under rainfed agroecosystem and is grown either sole or in association with short duration annuals as intercrops or with perennial tree crops in an agroforestry system. However, the studies on influence of tree-crop interface of neem and pigeonpea on economical returns especially the directional influence of bund planted neem trees on the pigeonpea crops is minimal. Hence, specific objectives of this study were; (1) to analyze the energy efficiencies of the system and (2) to know the economic benefits of the system as influenced by direction and distances of neem trees in north-eastern part of Karnataka.

\section{Materials and Methods}

The present investigation was carried out on farmer's field in Yadagir district of Karnataka, India during 2018-19. The study site was located $16^{\circ} 43^{\prime} \mathrm{N}$ latitude and $76^{\circ} 40^{\prime}$ E longitude at an altitude of $488 \mathrm{~m}$ above mean sea level and falls under Agro-climatic Zone- II of Karnataka. The zone characterized with semi-arid climatic condition with short monsoon, mild winter and hot summer and the average annual rainfall of the experimental site is $745 \mathrm{~mm}$. However, during the experimental period (2018-19) the annual rainfall received was $550 \mathrm{~mm}$ with 38 rainy days and the average minimum and maximum temperatures recorded were 17.74 and $34.20{ }^{\circ} \mathrm{C}$, respectively. Further, majority of the soils in the zone are deep black cotton to block soils, red soils and red sandy loamy soils are also found in some pockets. However, the soil of the study site was red sandy loamy belonging to Alfisols with low to medium nutrients.

The farmer retained neem trees on the bund in two direction north-south and east-west and an average age of the trees was 25 years and the density varied from 40 to 50 trees in each directions. Ten trees in each direction were 
randomly selected and measured for their height, girth, crown spread, biomass and volume (Table 1) by non harvesting method by using following equation (Chaturvedi and Khanna, 1981).

Volume $=\left(\mathrm{g}^{2} / 4 \pi\right) \mathrm{h}$; Where, $\mathrm{g}$ is girth at breast height $(\mathrm{cm}), \mathrm{h}$ is bole height $(\mathrm{m})$ and $\pi$ is 3.142

The tree height was measured with help of Ravi altimeter from the ground level to the tip of the tree and expressed in meter, bole height is measured from ground to crown point and expressed in meter, tree girth at breast height $(1.37 \mathrm{~m})$ from the ground level was measured, and canopy spread was determined at east west and north - south directions using measuring tape and expressed in meter.

The experiment was laid out in a split plot design with 3 replications and 12 treatment combinations with selective randomization with one outside control with net plot size of $3.6 \mathrm{~m} \times 4.8 \mathrm{~m}$ for each treatment. Directions from tree line $\left(\mathrm{M}_{1^{-}}\right.$Eastern direction, $\mathrm{M}_{2^{-}}$ Western direction, $\mathrm{M}_{3}$ - Northern direction and $\mathrm{M}_{4}$ - Southern direction) formed the main plots and distances from tree line $\left(\mathrm{S}_{1}-0\right.$ to 5.4 $\mathrm{m}, \mathrm{S}_{2^{-}} 5.4$ to $10.8 \mathrm{~m}$ and $\mathrm{S}_{3^{-}} 10.8$ to $16.2 \mathrm{~m}$ ) formed the subplots. Observations on pigeonpea (cv. TS R) seed yield was recorded at harvest in net plot size of $29.16 \mathrm{~m}^{-2}$.

Energy efficiency of the agroforestry systems were calculated by the energy ratio between input and output used. The input values such as human labour, machinery, bullock, diesel fuel, fertilizers, pesticides, seeds were converted to energy equivalents by multiplying with energy efficiency and outputs such as grain yield, tree biomass, fruit field and other products were also converted in terms of energy by multiplying with energy coefficients and expressed mean energy (MJ $\mathrm{ha}^{-1}$ ) per hectare. The detailed energy coefficient used for the study is given in (Appendix - I). Based on energy equivalents of input and output, energy use efficiency and net energy were calculated by following equations (Ghorbani et al., 2011).

$$
\operatorname{EUE}\left(\text { Energy Use Efficiency) }=\frac{\text { Energy output }\left(\mathrm{MJ} \mathrm{ha}^{-1}\right)}{\text { Energy input }\left(\mathrm{MJ} \mathrm{ha}^{-1}\right)}\right.
$$

Net Energy $=$ Energy output $\left(\mathrm{MJ} \mathrm{ha}^{-1}\right)-$ Energy input $\left(\mathrm{MJ} \mathrm{ha}^{-1}\right)$

Cost of cultivation was computed by considering the present prices of inputs prevailed during their use for different treatments and cost of establishment of neem was not accounted. Similarly, the ruling market price for pigeonpea, neem-wood and fruits were considered for working out gross returns. The cost of cultivation was deducted in gross returns to arrive at net profit per hectare. Benefit cost ratio was worked by dividing the gross returns to cost of cultivation. Only third order interactions were considered for interpretation using Duncan's Multiple Range Test in M-STAT.C software.

\section{Results and Discussion}

Energy input and output status of pigeonpea with neem trees and control (pigeonpea without neem) is shown in Table 2. Energy input for pigeonpea with neem trees and those of control were not much differ (4886.7 and 4855.2 $\mathrm{MJ} \mathrm{ha}^{-1} \mathrm{yr}^{-1}$ respectively).

Among the directions, there were no significant difference in net energy gain (NE) and energy use efficiency (EUE), but numerically these were maximum in eastern side of tree line $\left(\mathrm{M}_{1}-8466 \mathrm{MJ} \mathrm{ha}^{-1} \mathrm{yr}^{-1}\right.$ and 2.73 , respectively) followed by southern side and the least in western side $\left(\mathrm{M}_{2^{-}}-8195 \mathrm{MJ}\right.$ ha ${ }^{1} \mathrm{yr}^{-1}$ and 2.68 , respectively) of tree line.

As increase in the distance from tree line, there were increases in the NE and EUE. Plants far away from neem tree line $\left(\mathrm{S}_{3}\right)$ recorded significantly high (11275 $\mathrm{MJ} \mathrm{ha}^{-1} \mathrm{yr}^{-}$ 
${ }^{1}$ and 3.31 , respectively), while those planted nearer the tree line $\left(\mathrm{S}_{1}\right)$ recorded lower $(5864$ $\mathrm{MJ} \mathrm{ha}^{-1} \mathrm{yr}^{-1}$ and 2.20, respectively).

However, interaction between direction and distance, pigeonpea far away from tree line $\left(\mathrm{M}_{1-4} \mathrm{~S} 3\right)$ recorded significantly $\mathrm{NE}$ and EUE and those planted near the tree line recorded lowest. Sole crop of pigeonpea had NE and EUE were $6124 \mathrm{MJ} \mathrm{ha}^{-1} \mathrm{yr}^{-1}$ and 2.26 respectively.

Thus, agroforestry systems are highly efficient in energy use efficiency compared to the control. This could be mainly attributed to the additional energy from the tree biomass which contributes 13 to $20 \%$ of the total energy compared to control. Further, agroforestry systems are more sustainable than the control. The findings are in line with Nautiyal et al., (1998) who worked out energy analysis of agroforestry systems in Garhwal Himalaya, India and reported higher energy use efficiency ratio in sequential agroforestry system (197.3) followed by home garden (0.78) and simultaneous agroforestry (0.63). Similarly, Rita et al., (2002) analyzed energy efficiency of large cardamom grown under Alnus nepalensis and natural forest and the findings revealed that higher energy fixation and storage by 1.57 and 1.44 times respectively in cardamom grown under Alnus nepalensis than under natural forest.

The acceptance of any technology by the farmer ultimately depends on economics involved in the production system. Among the different indicators of monetary efficiency, the economics in terms of net return and benefit cost ratio have a greater impact on acceptance of technology. Cost of cultivation of the agroforestry system was ₹ 15417/- per ha irrespective of direction and distance from the tree line (Table 3).

The gross returns were the maximum (₹ $55583 /-$ ha $^{-1}$ ) with pigeonpea on southern side at a distance of 10.8 to $16.2 \mathrm{~m}\left(\mathrm{M}_{4} \mathrm{~S}_{3}\right)$; other directions at similar distances $\left(\mathrm{M}_{1-3} \mathrm{~S}_{3}\right)$ were comparable with the former treatment combination $\left(\mathrm{M}_{4} \mathrm{~S}_{3}\right)$. Better economic returns of pigeonpea on the southern direction of the tree line could be attributed to better yield attributing characters (Fig. 1) than other directions.

However, pigeonpea planted near the tree line at $<5.4 \mathrm{~m}$ on the western side $\left(\mathrm{M}_{2} \mathrm{~S}_{1}\right)$ of the tree line recorded the lowest gross returns (₹ $31029 /-$ ha $^{-1}$ ) followed by other combinations closer to neem tree line irrespective of the direction of planting $\left(\mathrm{M}_{1-3} \mathrm{~S}_{1}\right)$. Similar were the trends in net returns and $\mathrm{B}$ : $\mathrm{C}$.

Table.1 Growth performance of neem trees in experimental site

\begin{tabular}{|c|c|c|c|c|}
\hline Particulars & \multicolumn{2}{|c|}{ North-south direction } & \multicolumn{2}{|c|}{ East-west direction } \\
\hline 1. Tree density ha ${ }^{-1}$ & \multicolumn{2}{|c|}{44} & \multicolumn{2}{|c|}{44} \\
\hline 2. Age & \multicolumn{2}{|l|}{25 years } & \multicolumn{2}{|l|}{25 years } \\
\hline 3. Tree height (m) & \multicolumn{2}{|l|}{$13.2( \pm 1.54)$} & \multicolumn{2}{|l|}{$12.6( \pm 1.88)$} \\
\hline 4. Bole height (m) & \multicolumn{2}{|l|}{$3.4( \pm 0.62)$} & \multicolumn{2}{|l|}{$3.2( \pm 0.69)$} \\
\hline 5. GBH $(\mathrm{cm})$ & \multicolumn{2}{|l|}{$131.6( \pm 27.27)$} & \multicolumn{2}{|l|}{$126.5( \pm 31.91)$} \\
\hline \multirow[t]{3}{*}{ 6. Canopy spread (m) } & Towards east & $5.7( \pm 0.88)$ & Towards north & $5.8( \pm 0.98)$ \\
\hline & Towards west & $6.1( \pm 0.89)$ & Towards south & $5.6( \pm 0.88)$ \\
\hline & Sum & $11.8( \pm 1.67)$ & Sum & $11.4( \pm 1.63)$ \\
\hline 7. Tree volume $\left(\mathrm{m}^{3}\right.$ tree $\left.^{-1}\right)$ & \multicolumn{2}{|c|}{$0.47( \pm 0.054)$} & \multicolumn{2}{|c|}{$0.41( \pm 0.053)$} \\
\hline
\end{tabular}

Note: Values in the parentheses indicate the standard deviation 
Table.2 Energy Use Efficiency (EUE) of pigeonpea-neem based agroforestry system

\begin{tabular}{|c|c|c|c|c|}
\hline Treatments & $\begin{array}{c}\text { Input } \\
\left(\mathrm{MJ} \mathrm{ha}^{-1} \mathrm{yr}^{-1}\right)\end{array}$ & $\begin{array}{c}\text { Output } \\
\left(\mathbf{M J ~ h a}^{-1} \mathbf{y r}^{-1}\right)\end{array}$ & $\begin{array}{l}\text { Net Energy } \\
\text { Gain } \\
\left(\mathbf{M J ~ h a}^{-1} \mathbf{y r}^{-1}\right)\end{array}$ & $\begin{array}{c}\text { Energy Use } \\
\text { Efficiency } \\
\text { (EUE) }\end{array}$ \\
\hline \multicolumn{5}{|c|}{ DIRECTION (M) } \\
\hline $\mathbf{M}_{1}$ & 4886.7 & $13352^{\mathrm{a}}$ & $8466^{\mathrm{a}}$ & $2.73^{\mathrm{a}}$ \\
\hline $\mathbf{M}_{2}$ & 4886.7 & $13082^{a}$ & $8195^{\mathrm{a}}$ & $2.68^{\mathrm{a}}$ \\
\hline $\mathbf{M}_{3}$ & 4886.7 & $13095^{\mathrm{a}}$ & $8208^{\mathrm{a}}$ & $2.68^{\mathrm{a}}$ \\
\hline $\mathbf{M}_{4}$ & 4886.7 & $13348^{\mathrm{a}}$ & $8461^{\mathrm{a}}$ & $2.73^{\mathrm{a}}$ \\
\hline S.Em \pm & 4886.7 & 133 & 142 & 0.03 \\
\hline \multicolumn{5}{|c|}{ DISTANCE (S) } \\
\hline $\mathbf{S}_{1}$ & 4886.7 & $10751^{\mathrm{c}}$ & $5864^{\mathrm{c}}$ & $2.20^{\mathrm{c}}$ \\
\hline $\mathbf{S}_{2}$ & 4886.7 & $12745^{b}$ & $7859^{b}$ & $2.61^{b}$ \\
\hline $\mathbf{S}_{\mathbf{3}}$ & 4886.7 & $16162^{\mathrm{a}}$ & $11275^{\mathrm{a}}$ & $3.31^{\mathrm{a}}$ \\
\hline S.Em \pm & 4886.7 & 116 & 123 & 0.03 \\
\hline \multicolumn{5}{|c|}{ INTERACTION (M x S) } \\
\hline $\mathbf{M}_{1} \mathbf{S}_{1}$ & 4886.7 & $10953^{c}$ & $6066^{\mathrm{d}}$ & $2.24^{d}$ \\
\hline $\mathbf{M}_{1} \mathbf{S}_{2}$ & 4886.7 & $12711^{b}$ & $7825^{\mathrm{bc}}$ & $2.60^{\mathrm{bc}}$ \\
\hline $\mathbf{M}_{1} \mathbf{S}_{3}$ & 4886.7 & $16393^{\mathrm{a}}$ & $11506^{\mathrm{a}}$ & $3.35^{\mathrm{a}}$ \\
\hline $\mathbf{M}_{2} \mathbf{S}_{1}$ & 4886.7 & $10695^{c}$ & $5808^{d}$ & $2.19^{d}$ \\
\hline $\mathbf{M}_{2} \mathbf{S}_{2}$ & 4886.7 & $12336^{b}$ & $7450^{c}$ & $2.52^{c}$ \\
\hline $\mathbf{M}_{2} \mathbf{S}_{3}$ & 4886.7 & $16215^{\mathrm{a}}$ & $11328^{\mathrm{a}}$ & $3.32^{\mathrm{a}}$ \\
\hline $\mathbf{M}_{3} \mathbf{S}_{1}$ & 4886.7 & $10533^{c}$ & $5646^{d}$ & $2.16^{d}$ \\
\hline $\mathbf{M}_{3} \mathbf{S}_{2}$ & 4886.7 & $12751^{b}$ & $7864^{b c}$ & $2.61^{b c}$ \\
\hline $\mathbf{M}_{3} \mathbf{S}_{3}$ & 4886.7 & $16001^{\mathrm{a}}$ & $11114^{\mathrm{a}}$ & $3.27^{\mathrm{a}}$ \\
\hline $\mathbf{M}_{4} \mathbf{S}_{1}$ & 4886.7 & $10823^{c}$ & $5937^{d}$ & $2.21^{\mathrm{d}}$ \\
\hline $\mathbf{M}_{4} \mathbf{S}_{2}$ & 4886.7 & $13182^{b}$ & $8296^{b}$ & $2.70^{b}$ \\
\hline $\mathbf{M}_{4} \mathbf{S}_{3}$ & 4886.7 & $16039^{a}$ & $11152^{\mathrm{a}}$ & $3.28^{\mathrm{a}}$ \\
\hline S.Em \pm & -- & 231 & 247 & 0.05 \\
\hline \multicolumn{5}{|c|}{ REST VS. CONTROL } \\
\hline Control & 4855.4 & 10979 & 6124 & 2.26 \\
\hline S.Em \pm & -- & 226 & 238 & 0.05 \\
\hline C.D. $(P=0.05)$ & -- & 659 & 693 & 0.14 \\
\hline
\end{tabular}


Table.3 Economics of agroforestry system

\begin{tabular}{|c|c|c|c|c|}
\hline Treatments & $\begin{array}{c}\text { Cost of } \\
\text { cultivation } \\
\left(₹ \text { ha }^{-1}\right)\end{array}$ & $\begin{array}{l}\text { Gross returns } \\
\quad\left(₹ \text { ha }^{-1}\right)\end{array}$ & $\begin{array}{l}\text { Net returns } \\
\left(₹ \text { ha }^{-1}\right)\end{array}$ & B:C \\
\hline \multicolumn{5}{|c|}{ DIRECTION (M) } \\
\hline $\mathbf{M}_{1}$ & 15417 & $41984^{\mathrm{bc}}$ & $26567^{\mathrm{bc}}$ & $3.04^{\mathrm{bc}}$ \\
\hline $\mathbf{M}_{2}$ & 15417 & $40869^{c}$ & $25452^{\mathrm{c}}$ & $2.97^{\mathrm{c}}$ \\
\hline $\mathbf{M}_{3}$ & 15417 & $43448^{\mathrm{ab}}$ & $28031^{\mathrm{ab}}$ & $3.10^{\mathrm{ab}}$ \\
\hline $\mathbf{M}_{4}$ & 15417 & $44492^{a}$ & $29075^{\mathrm{a}}$ & $3.16^{\mathrm{a}}$ \\
\hline S.Em \pm & - & 587 & 536 & 0.04 \\
\hline \multicolumn{5}{|c|}{ DISTANCE (S) } \\
\hline $\mathbf{S}_{1}$ & 15417 & $32523^{c}$ & $17106^{\mathrm{c}}$ & $2.41^{\mathrm{c}}$ \\
\hline $\mathbf{S}_{\mathbf{2}}$ & 15417 & $40744^{b}$ & $25327^{b}$ & $2.94^{\mathrm{b}}$ \\
\hline $\mathbf{S}_{\mathbf{3}}$ & 15417 & $54829^{\mathrm{a}}$ & $39412^{\mathrm{a}}$ & $3.85^{\mathrm{a}}$ \\
\hline S.Em \pm & - & 508 & 464 & 0.03 \\
\hline \multicolumn{5}{|c|}{ INTERACTION (M x S) } \\
\hline $\mathbf{M}_{1} \mathbf{S}_{1}$ & 15417 & $32092^{\mathrm{e}}$ & $16675^{\mathrm{ef}}$ & $2.40^{\mathrm{e}}$ \\
\hline $\mathbf{M}_{1} \mathbf{S}_{2}$ & 15417 & $39342^{\text {cd }}$ & $23925^{\mathrm{cd}}$ & $2.87^{\mathrm{cd}}$ \\
\hline $\mathbf{M}_{1} \mathbf{S}_{3}$ & 15417 & $54519^{\mathrm{a}}$ & $39102^{a}$ & $3.85^{\mathrm{a}}$ \\
\hline $\mathbf{M}_{2} \mathbf{S}_{1}$ & 15417 & $31029^{e}$ & $15612^{f}$ & $2.33^{\mathrm{e}}$ \\
\hline $\mathbf{M}_{2} \mathbf{S}_{2}$ & 15417 & $37795^{d}$ & $22378^{d}$ & $2.77^{\mathrm{d}}$ \\
\hline $\mathbf{M}_{2} \mathbf{S}_{3}$ & 15417 & $53784^{\mathrm{a}}$ & $38367^{\mathrm{a}}$ & $3.81^{\mathrm{a}}$ \\
\hline $\mathbf{M}_{3} \mathbf{S}_{1}$ & 15417 & $32886^{\mathrm{e}}$ & $17469^{\mathrm{ef}}$ & $2.41^{\mathrm{e}}$ \\
\hline $\mathbf{M}_{3} \mathbf{S}_{2}$ & 15417 & $42031^{\mathrm{bc}}$ & $26614^{\mathrm{bc}}$ & $3.00^{\mathrm{bc}}$ \\
\hline $\mathbf{M}_{3} \mathbf{S}_{3}$ & 15417 & $55429^{a}$ & $40012^{\mathrm{a}}$ & $3.87^{\mathrm{a}}$ \\
\hline $\mathbf{M}_{4} \mathbf{S}_{1}$ & 15417 & $34085^{\mathrm{e}}$ & $18668^{\mathrm{e}}$ & $2.49^{\mathrm{e}}$ \\
\hline $\mathbf{M}_{4} \mathbf{S}_{2}$ & 15417 & $43809^{b}$ & $28392^{b}$ & $3.12^{\mathrm{b}}$ \\
\hline $\mathbf{M}_{4} \mathbf{S}_{3}$ & 15417 & $55583^{\mathrm{a}}$ & $40166^{\mathrm{a}}$ & $3.88^{\mathrm{a}}$ \\
\hline S.Em \pm & - & 1016 & 929 & 0.07 \\
\hline \multicolumn{5}{|c|}{ REST VS. CONTROL } \\
\hline Control & 15256 & 45259 & 29842 & 2.97 \\
\hline S.Em \pm & - & 979 & 912 & 0.06 \\
\hline C.D. $(P=0.05)$ & - & 2858 & 2661 & 0.19 \\
\hline
\end{tabular}


The net returns and B: $\mathrm{C}$ were the maximum (₹ 40166/- ha ${ }^{-1}$ and 3.88, respectively) with pigeonpea on southern side at a distance of 10.8 to $16.2 \mathrm{~m}\left(\mathrm{M}_{4} \mathrm{~S}_{3}\right)$; other directions at similar distances $\left(\mathrm{M}_{1-3} \mathrm{~S}_{3}\right)$ were comparable with the former treatment combination $\left(\mathrm{M}_{4} \mathrm{~S}_{3}\right)$. The economics followed crop yield (Fig. 1).

The gross returns and $\mathrm{B}: \mathrm{C}$ were maximum at 10.8 to $16.2 \mathrm{~m}$ from the tree line over those that were planted closer to tree line at $<5.4 \mathrm{~m}$ could be attributed to better yield. This was on the expected line as there will be greater competition for resources nearer the tree line as trees were already established (25 years age) and had greater root extensions in the soil (Table 1). Further, the wider tree canopy which can shade the plants and those away depending on solar movement also had its impact on crop performance which was rather more near the tree than away from it.

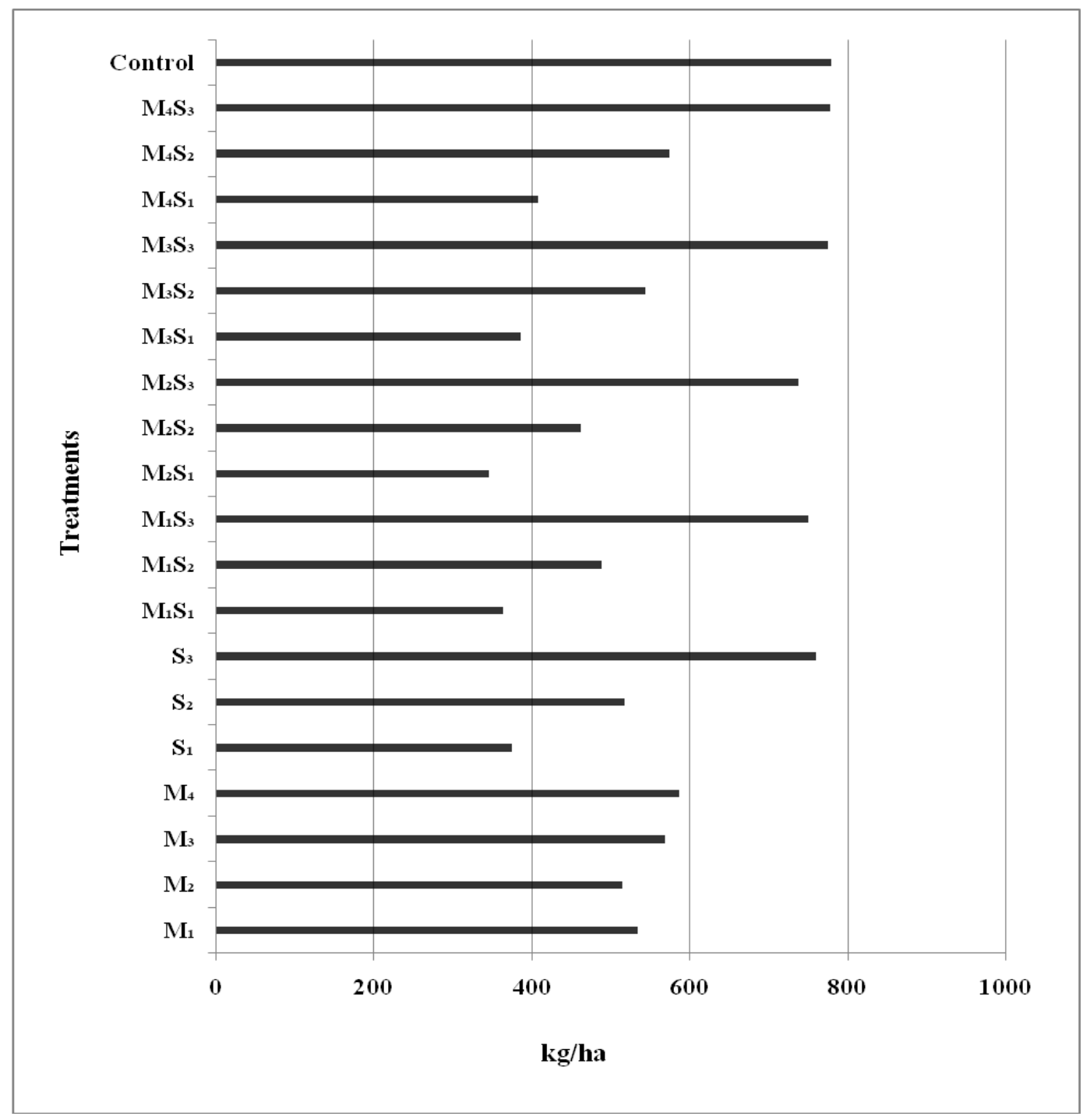

Direction from tree row $\mathrm{M}_{3}$ : Northern direction $\mathrm{S}_{1}: 0-5.4 \mathrm{~m}$
$\mathrm{M}_{1}$ : Eastern direction

$\mathrm{M}_{4}$ : Southern direction

$\mathrm{S}_{2}: 5.4-10.8 \mathrm{~m}$
$\mathrm{M}_{2}$ : Western direction

$\mathrm{S}$ : Distance from tree line $\mathrm{S}_{3}: 10.8-16.2 \mathrm{~m}$

Fig.1 Yield of pigeonpea as influenced by different directions and distances from neem tree line and their interactions in agroforestry system 
Interaction between directions and distances of pigeonpea from neem in agroforestry system revealed significant differences in economical returns. Pigeonpea planted near the tree line at $<5.4 \mathrm{~m}$ on the western side $\left(\mathrm{M}_{2} \mathrm{~S}_{1}\right)$ of the tree line recorded the lowest net returns and B: C (₹ 15612/- $\mathrm{ha}^{-1}$ and 2.33, respectively) followed by other combinations closer to neem tree line irrespective of the direction of planting $\left(\mathrm{M}_{1-3} \mathrm{~S}_{1}\right)$. Sole crop of pigeonpea had gross and net returns and B: C of 45259 and $₹$ 29842/- $\mathrm{ha}^{-1}$ and 2.97 respectively.

Interestingly the agroforestry system of pigeonpea + neem with pigeonpea at $>10.8 \mathrm{~m}$ irrespective of directions of planting $\left(\mathrm{M}_{1-4} \mathrm{~S}_{3}\right)$ recorded higher returns and $\mathrm{B}$ : $\mathrm{C}$ than sole pigeonpea, while those planted at 5.4-10.8 m distance irrespective of the directions from neem tree line were comparable with sole pigeonpea.

In all, the economics followed crop yield (Fig. 1) and economic returns obtained from the tree component. Thus, agroforestry system found to influence farm economics and in the present study it is the distance of agricultural crops from the tree line matter much than the direction from the tree line or orientation of tree line. Similarly, many earlier workers reported the benefits of agroforestry system economically and for the ecosystem service benefits including the traditional systems (Doddabasawa et al., 2017).

The economic analysis of 10 years old Melia azadirach-Soybean based agroforestry system was carried out by Patil et al., (2012) at Main Agricultural Research Station, University of Agricultural Sciences, Dharwad, India and they recorded higher gross return in Melia azadirach-Soybean based agroforestry system (₹ 10,502/- $\mathrm{ha}^{-1} \mathrm{yr}^{-1}$ ) and B: C of 1.86 as compared to sole soybean (₹ 6,410/- $\mathrm{ha}^{-1} \mathrm{yr}^{-1}$ with B: C 1.73).
Over all, agroforestry system involving neem and pigeonpea under rainfed condition in Zone II - North eastern dry zone of Karnataka with crop at $>10.8 \mathrm{~m}$ distance from neem is profitable and ecologically desirable than sole crop.

\section{References}

Chaturvedi, A. N. and Khanna, L. S., 1981, Forest Mensuration. International book distributors, Dehradun, India.

Chittapur, B. M. and Patil, D. K., 2017, Ecosystem services rendered by tree based land use systems. Indian J. Agric. Sci., 87 (11): 1419-1429.

Chittapur, B. M., Umesh, M. R. and Patil, D. K., 2017, On-farm crop diversity for sustainability and resilience in farming - A review. Agric. Rev., 38(3): 191-200.

Doddabasawa, Chittapur, B. M. and Mahadeva Murthy, M., 2017, Structural analysis and mapping of agroforestry systems under irrigated ecosystem in north-eastern part of Karnataka, India. Agroforest. Syst., https://doi.org/10.1007/s10457-018-0277-8

Doddabasawa, Chittapur, B. M. and Mahadeva Murthy, M., 2017a, Assessment of tree diversity in agroforestry systems under irrigated ecosystem. Int. J. Curr. Microbiol. App. Sci., 6(10): 3111-3127.

Jose, S. 2009. Agroforestry for ecosystem services and environmental benefits: an overview. Agrofor. Syst, 76(1): 1-10.

Nautiyal, S., Maikhuri, R. K., Semwal, R. L., Rao, K. S. and Saxena, K. G., 1998, Agroforestry systems in the rural landscape- a case study in Garhwal Himalaya, India. Agrofor. Syst, 41: 151165.

Patil, S. J., Mutanal, S. M. and Patil, H. Y., 2012, Melia azedarach based agroforestry system in transitional tract of Karnataka. Karnataka J. Agric. Sci., 25(4): 460-462.

Rita, S., Sharma, G. and Sharma, E., 2002, Energy efficiency of large cardamom grown under Himalayan alder and natural forest. Agrofor. Syst., 56: 233-239. 


\section{How to cite this article:}

Honnayya, M. G., Doddabasawa and Chittapur, B. M. 2020. Energy Efficiency and Economical Benefits of Pigeonpea [Cajanus cajan (L.) Millsp.] - Neem (Azadirachta indica A. Juss.) Based agroforestry System under Rainfed Condition in North-Eastern Karnataka, India. Int.J.Curr.Microbiol.App.Sci. 9(03): 2200-2208.

doi: https://doi.org/10.20546/ijcmas.2020.903.252 